\title{
Serbest Bölgelerde Vergi Uygulamalarının Yeni Düzenlemeler Çerçevesinde Değerlendirilmesi
}

\author{
Evaluation of the Tax Practices in Free Zones Within the Framework of New \\ Regulations \\ Sevgi SÜMERLI SARIGÜL* \\ Betül ALTAY TOPCU**
}

$\ddot{O} Z$

Serbest bölgeler, bir ülkenin siyasi sinırları içinde olmakla birlikte, gümrük ve kambiyo mevzuatının uygulanması açısından gümrük bölgesi dı̧̧ında kalan alanlardır. Bu bölgeler öncelikli olarak ihracatı artırmak, yabancı sermaye girişini kolaylaştırmak ve döviz rezervlerini artırmak gibi gelişmiş ve gelişmekte olan ülkelerin sürdürülebilir ekonomik büyümesinde önemli bir rol oynamaktadır. Firmaların serbest bölgelere yönelmesinin en önemli nedeni, bu bölgelerin firmalara sağlamış olduğu vergisel avantajlardır. Bu çallşmanın amacı, 24 Şubat 2017 tarih ve 29989 sayll Resmi Gazetede yayımlanan "6772 Sayll Serbest Bölgeler Kanunu ile Bazı Kanun ve Kanun Hükmünde Kararnamelerde (KHK) Değişiklik Yapılmasına Dair Kanun” sonrasında, serbest bölgelerle ilgili yapılan vergisel ve diğer yasal düzenlemelerin incelenmesidir.

\author{
ANAHTAR KELIMELER \\ Serbest Bölgeler, Katma Dĕ̌er Vergisi, Gelir Vergisi, Kurumlar Vergisi
}

\begin{abstract}
Free zones are within the political borders of a country, but they are outside from the customs territory for the implementation of customs and foreign exchange legislation. These regions primarily play an important role in the sustainable economic growth of both developed countries and developing countries, such as increasing exports, facilitating foreign capital inflow and increasing foreign exchange reserves. The most important reason why firms move towards free zones is the tax advantages that these regions provide to companies. The aim of this study is to examine the tax law and other legal regulations regarding the free zones after the Law no. 6772 on Free Zones Law and some Laws and Decree Laws (Decree Law) published in the Official Gazette No. 29989 dated 24 February 2017.
\end{abstract}

\section{KEYWORDS}

Tax Free Regions, Value Added Tax, Individual Tax, Corporate Tax,

\begin{tabular}{|c|c|c|}
\hline \multicolumn{2}{|c|}{$\begin{array}{c}\text { Makale Geliş Tarihi /Submission Date } \\
13.11 .2018\end{array}$} & \multicolumn{1}{c|}{$\begin{array}{c}\text { Makale Kabul Tarihi / Date of Acceptance } \\
\text { O2.01.2019 }\end{array}$} \\
\hline \multirow{3}{*}{ Atıf } & $\begin{array}{l}\text { Sarı̈ül, S.S., Topcu, B.A. (2019). Serbest Bölgelerde Vergi Uygulamalarının Yeni Düzenlemeler Çerçevesinde } \\
\text { Değerlendirilmesi. Selçuk Üniversitesi Sosyal Bilimler Meslek Yüksekokulu Dergisi, 22 (1), 133-142. }\end{array}$ \\
\hline
\end{tabular}

\footnotetext{
* Dr. Öğr. Üyesi, Kayseri Üniversitesi MYO, ssumerli@erciyes.edu.tr, ORCID: 0000-0002-3820-6288

** Doç. Dr., Kayseri Üniversitesi MYO, batopcu @erciyes.edu.tr, ORCID: 0000-0003-2044-4568
} 


\section{GİRIŞ}

Serbest bölgeler amaçları, türleri ve özellikleri açısından ait oldukları dönemin ve kuruldukları yerin ekonomik ve siyasi yapısının belirlenmesinde önemli bir rol oynamıştır. Serbest bölgeler, dünyada 20. yüzyılın ikinci yarısından itibaren hızla artış göstermiştir. Bu bölgeler, hem gelişmiş hem de gelişmekte olan ülkelerde; dış ticaret hacminin artması, ödemeler dengesine katkı sağlaması, teknoloji transferinin sağlanması, sanayileşme, istihdam olanaklarının yaratılması, dış ticaretin kolaylaştırılması gibi hususlarda önemli yararlar sağlamıştır (Orhan, 2003: 117).

Günümüzde serbest bölgeler gelişmiş ülkelerde çok önemli lojistik işlevlerin yürütüldüğü önemli ticaret merkezleri haline gelmiştir. Gelişmekte olan ülkelerde ise dış ticaret ve yatırım imkânlarından daha fazla yararlanılan ve yeni istihdam olanaklarının oluşturulduğu yerler haline gelmiştir. Gelişmekte olan ülkelerin kalkınma öncelikleri; üretim ve ihracatın teşvik edilmesi ile dış piyasalarda rekabet gücünün artırılması, daha iyi istihdam olanaklarının yaratılması, teknolojinin geliştirilmesi gibi unsurlar yoluyla sürdürülebilir bir ekonomik büyümenin sağlanmasıdır (Tüzün Rad ve diğ., 2016: 289).

Küreselleşme eğilimlerinin artması ile birlikte, bazı malların ithalatı esnasında, gümrük tarifelerinin uygulanmadığı birtakım istisnalar ortaya çıkmıştır. Özel dış ticaret rejimleri adı verilen bu istisnaların öncelikli olanları; transit ticaret rejimi, antrepo rejimi, sınır ve kıyı ticareti rejimi, geçici kabul rejimi ve serbest bölge rejimidir (Arslan ve Yaprakl1, 2007: 92).

Serbest bölgeler fiziki olarak ülkenin diğer bölümlerinden ayrılan, ancak bir ülkenin siyasi sınırları içerisinde bulunan yerlerdir. Bu bölgeler, bir ülkenin gümrük hattı dışında sayıldığı için, söz konusu bölgelerde iktisadi, ticari ve mali alanda hukuki ve idari düzenlemeler kısmen uygulanmakta veya uygulanmamaktadır. $\mathrm{Bu}$ nedenle serbest bölgelerde ticari ve sınai faaliyetlerde bulunan firmalar, büyük ölçekli teşviklerden yararlanma imkânı bulurlar (Avcı ve Erek, 2018: 200). Serbest bölge kavramına ilişkin çok sayıda tanımlama vardır. Ancak her tanımda yer alan ortak kavram "Dış Ticaretin Kolaylaştırılması"dır (Türkgenci, 2008: 49).

Bu çalışmanın amacı, serbest bölgelerin 6772 Sayılı Kanun ile serbest bölgelerdeki yeni vergisel ve yasal düzenlemelerin incelenmesi ve değerlendirilmesidir. Çalışma dört bölümden oluşmaktadır. Çalışmanın birinci bölümünde, ilgili kanunda ve literatürde yer alan serbest bölge kavramları ve serbest bölgelerin kuruluş amaçları hakkında bilgi verilecektir. İkinci bölümde, serbest bölge türleri ve özelliklerine değinilecektir. Üçüncü bölümde serbest bölgelerden sağlanan avantajlar ve serbest bölgelerin ekonomik etkileri üzerinde durulacaktır. Dördüncü bölümünde, serbest bölgelerde yeni vergisel ve yasal düzenlemeler, ilgili mevzuata göre değerlendirilecektir. Çalışmada son olarak sonuç kısmına yer verilecektir.

\section{SERBEST BÖLGE KAVRAMI VE SERBEST BÖLGELERIN KURULUŞ AMAÇLARI}

Çalışmanın bu bölümünde literatürde ve ilgili kanunda yer alan bazı serbest bölge tanımlarına yer verilecektir. Ayrıca serbest bölgelerin kuruluş amaçları üzerinde durulacaktır.

\subsection{Serbest Bölge Kavramı}

Uluslararası ticarete konu olan malların ülke sınırından geçişi sırasında, hangi ülkeye varmış ise o ülkenin gümrük vergisine tabidir ve bu mallardan Gümrük Tarife İstatistik Pozisyonu (GTIP) cetvellerinde belirlenen oranlarda gümrük vergisi tahsil edilir. Fakat özel dış ticaret rejimleri olarak da adlandırılan bazı dış ticaret işlemleri ise o ülkenin gümrük rejimine tabi değildir. Geçici ihracat, geçici ithalat, antrepo, serbest bölgeler, sınır ve kıyı ticareti, transit taşımacılık ve bedelsiz ithalat başlıca özel dış ticaret rejimleri arasında yer alır (Avc1 ve Erek, 2018: 205).

Serbest bölgeler en yaygın tanım olarak, bir ülkenin siyasi sınırları içerisinde yer alan ve gümrük mevzuatının uygulanması bakımından gümrük hattı dışında sayılan yerlerdir. Bir başka tanımlamaya göre serbest bölge, bir ülkenin mevcut siyasi sınırları içerisinde bulunmakla beraber; gümrük vergisi, gelir ve kurumlar vergisi gibi vergi sınırları dışında kalan, ticari ve sınai faaliyetlere ilişkin işlemlerin kolaylaştırılmasını sağlamak amacıyla ekonomiye katkı sağlayan, devlet müdahalesinin en aza indirgendiği bir nevi üçüncü ülke konumundaki yerlerdir (Bakan ve Gökmen, 2014: 35).

Literatürde yer alan bir diğer tanıma göre bu bölgeler, bir ülkenin siyasi olarak çizilmiş sınırları içerisinde bulunan, o ülkenin gümrük sınırları dışında yer alan, ülkenin diğer bölgelerine göre sınai ve ticari faaliyetler açısından teşvik edilen, sınırları belirli yerlerdir (Ebiri, 2000: 45).

Serbest bölge ile ilgili literatürde yapılan tanımların yanı sıra, Gümrük Kanunu'nun 152. Maddesi ve Serbest Bölgeler Kanunu'nun 6. Maddesi'ne gereğince serbest bölgeler; Türkiye Gümrük Bölgesi'nin parçaları olmakla birlikte, Türkiye Gümrük Bölgesi dışında yer alan, serbest dolaşımda olmayan bir eşyanın herhangi bir gümrük rejimine tabi tutulmadan, gümrük mevzuatında öngörülen haller dışında kullanılmamak ya da tüketilmemek şartıyla konulduğu yerler olarak tanımlanmaktadır. Bu açıdan serbest bölgeler, ithalat vergileri 
ve ticaret politikası önlemlerinin uygulanması açısından, serbest dolaşımdaki bir eşyanın, bir serbest bölgeye konulması nedeniyle eşyanın ihracına bağlı olanaklardan yararlanılan yerlerdir.

Tanımlarda da görüldüğü üzere, serbest bölgeler özellikle gümrük vergileri gibi çeşitli dış ticaret kısıtlamalarının dışında bırakılmış alanlardır. Bu alanlar, gümrük imtiyazlarının sağlanması ile birlikte, yatırımcıların çeşitli vergi muafiyetlerinden yararlandırıldı̆̆ı, dünya standartlarında teknolojik altyapı olanaklarının geliştirildiği ve ihracata yönelik üretim yapılmasına olanak sağlayan, çeşitli türlerde teşviklerin sağlandığ 1 yerlerdir.

Serbest bölgeler kuruluş amaçları, kanuni temelleri, fonksiyonları ve yapısal özellikleri bakımından uygulamada değişik isimler alabilmektedir. Serbest bölgeler, gelişmekte olan ülkelerde ihracatın artırılması, ülkeye gelecek yabancı yatırımların özendirilmesi, teknoloji ve bilgi transferinin sağlanması ve yeni istihdam imkânlarının oluşturulması gibi amaçlara hizmet etmektedir. Bu yüzden serbest bölgeler, İhraç İşlem Bölgesi veya Serbest Üretim Bölgeleri olarak da isimlendirilmektedir (Öztürk, 2013: 76). Gelişmiş ülkelerde faaliyet gösteren serbest bölgelerde ticaret ön plandadır. Bu açıdan bu bölgeler, Dış Ticaret Bölgesi veya Serbest Ticaret Bölgesi olarak da bilinmektedir (C1ll1, 2013: 11).

\subsection{Serbest Bölgelerin Amaçları}

Serbest bölgelerin amaçları şunlardır (Dabaour, 1999: 18; Gümüş, 2007: 48; Çetinkaya ve Bektaş, 2014: 55-56;):

- Yurtiçi yatırımları ve üretimi ihracat amaçlı artırmak,

- Yabanci sermaye yatırımlarını artırmak,

- Uluslararası ticareti ülkeye gelen yabancı sermaye ve teknoloji aracılığıyla artırmak,

- İhracata yönelik sanayinin gelişmesini teşvik etmek,

- Yeni iş olanakları sağlayarak istihdam sorununa çözüm bulmak,

- Yerli firmaların dünya piyasalarındaki fiyatlardan, hammadde temin edebilmelerini kolaylaştırmak,

- Gelişmiş üretim ve teknolojilerin ülkeye getirilmesine yardımcı olarak, ekonomik standartları yükseltmek,

- Diş ticaret için finansman imkânı yaratmak,

- Diş göçü azaltmak ve böylece işgücünü dengelemek,

- Yerli üreticilerin uluslararası rekabet güçlerini artırmak,

- Ülkeye döviz girişini artırmak,

- Re-export (yeniden ihracat) ve transit ticaret işlemlerinden sağlanan imkânlardan yararlanmak,

- Bankacılık işlemlerinin dış piyasalarda sürdürülebilirliğini sağlamaktır.

Serbest bölgelere, yukarıda belirtilen amaçları gerçekleştirmek için bazı vergisel teşvikler sağlanmaktadır. Serbest bölgelerin kurulmasında ilk amacın ne olduğunu, o ülkenin içinde bulunduğu ekonomik durum ve tercihleri belirlemektedir. Ülkelerin ekonomik durum ve tercihlerine yönelik olarak serbest bölgelerin öncelikli amacı ihracatı artırmak olabileceği gibi, özellikle gümrük vergilerinden muaf olarak ithalatı kolaylaştırmak da olabilir. Bazı ülkeler için ise ilk amaç, teknoloji transferi veya yabancı sermayenin ülkeye çekilmesi şeklinde ortaya çıkabilir (Uzay ve Tıraş, 2009: 250).

Serbest bölgeler, ithalatı gümrük vergisine bağlı mallardan gümrük vergisi alınmadığından re-export konusunda en avantajlı yerlerdir. Serbest bölgelerde faaliyet gösteren işletmeler, söz konusu malları re-export aşamasından önce ithal ettiklerinde gümrük vergisi ödemezler. Gümrük vergisi ödenmediği için de malın üretim maliyetlerinde bir düşüş meydana gelir ve mallar re-export işlemine tabi tutulduğunda ülkenin ihracat hacminde önemli bir yükselişe neden olur. Bu açıdan ülkeye giren dövizin, ülkenin rekabet gücüne olumlu etkisi vardır (Demirci ve Tarhan, 2016: 34-35).

\section{SERBEST BÖLGE TÜRLERİ VE ÖZELLİKLERİ}

Çalışmanın bu bölümünde serbest bölge türleri ve özellikleri değerlendirmeye tabi tutulmuştur.

\subsection{Serbest Bölge Türleri}

Farklı yapısal özellikleri olan serbest bölge çeşitleri; Serbest Bölge, Serbest Liman, İhraç Ürünleri İşleme Bölgesi, Dış Ticaret Bölgesi, Gümrüksüz Bölge, Özel Ekonomik Bölge, İkiz Fabrika, Serbest Ekonomik Bölge, Serbest Üretim Bölgesi, Serbest Ticaret Bölgesi, Endüstriyel Serbest Bölge, Vergisiz Bölge, Vergisiz Ticaret Bölgesi, Gümrüksüz Havaalanı, Yabancı Yatırım Bölgesi ve Antrepolardır. Söz konusu serbest bölge 
çeşitleri faaliyet konuları ve amaçlarına göre, Serbest Ticaret Bölgeleri ve Serbest Üretim Bölgeleri olmak üzere iki ana başlıkta değerlendirilebilir (Tümenbatur, 2012: 341-342).

Serbest bölgelerin sınıflandırılmasında üretim yönlü sürdürülen faaliyetler ve ticari yönlü sürdürülen faaliyetler olmak üzere iki kriter benimsenmektedir. Gelişmekte olan ülkelerin serbest bölgelerinde yürütülen faaliyetler, üretim yönlü faaliyetler şeklindedir. Gelişmiş ülkelerin serbest bölgelerinde ise, ticari yönlü sürdürülen faaliyetler daha yaygın olarak görülmektedir. Ticari yönlü faaliyetler depolama, malların gümrük vergisinden muaf olarak ithalatı, re-export mallarına yönelik olarak yapılan işlemler gibi faaliyetlerden oluşmaktadır. Bu bölgelerde yürütülen faaliyetler, bazı ülkelerde hem iç piyasaya hem de dış piyasaya yönelik olarak yürütülebilir. Bazen de serbest bölgeler sadece diş piyasaya yönelik olarak çalışırlar. Özellikle gelişmekte olan ülkelerde genel olarak, iç piyasaya yönelik üretim yasaklanmıştır (Demirci ve Tarhan, 2016: 35).

Serbest Ticaret Bölgeleri, serbest bölgelerde faaliyet gösteren işletmelere çeşitli avantajlar sağlamaktadır. $\mathrm{Bu}$ avantajlar; vergi muafiyeti, gümrüksüz ithalat ve personel alım hizmetlerini içerir. Bir serbest ticaret bölgesinin en büyük avantaj1, gümrük vergileri ve vergiler olmadan ihracat amaçlı olarak, montaj ve üretim için gerekli olan malzemelerin ve bileşenlerin ücretsiz, engelsiz olarak ithalatına izin vermesidir (Young, 1987, 369-384).

Serbest Ticaret Bölgeleri, gümrük ayrıcalıklarının tanınması açısından en önemli bölgelerdir. Bu bölgeler; sınırları belirlenmiş bir alanda, polis gözetimi altında, ülkenin gümrük sınırları dışında, ticari faaliyetleri kolaylaştırmak için kurulmuş alanlardır. Gümrük mevzuatına ilişkin uygulamaların kısmen ya da tamamen uygulanmadığı bu bölgelerde; ambalajlama, yeniden paketleme, dağıtma, sıralama, derecelendirme, test etme, sergileme, etiketleme, transit ticaret, depolama, hafif montaj, elleçleme ve gemilere gümrük vergisi ödemeden yeniden yükleme gibi faaliyetler yapılabilmektedir (Miyagiwa, 1993: 187-203; Yang, 2009: 278; Ural, 2009 : 9).

Serbest Ticaret Bölgeleri, ekonomi üzerinde olumlu bir etkiye sahip olma amacı ile kurulmuştur. Ulusal bir perspektiften bakıldığında, hükümetler Serbest Ticaret Bölgeleri'nde şu sonuçları aramaktadır: döviz değişimi sonucu kazanç, iş sağlanması ve gelirin yaratılması, doğrudan yabancı yatırımların çekiciliği ve teknoloji transferinin teşvik edilmesi (Yang, 2009: 278).

Serbest Üretim Bölgesi ise; ülkenin fiziki olarak diğer kısımlarından ayrılan, ülkenin kolluk kuvvetleri tarafından korunan, gümrük vergisi ve benzeri vergisel teşviklerden yararlandırılan alanlardır. Bu bölgeler; yabancı yatırımcılara gümrük vergisiz makine ve hammadde ithalinin sağlandığı, sermaye ve kâr transferi garantisinin verildiği, işlenmiş ve yarı işlenmiş malların ithalatının gümrük vergisinden muaf olduğu, işletme binasının sağlandığı bölgelerdir.

Serbest Üretim Bölgesini, Serbest Ticaret Bölgesinden farklı kılan en önemli özellik, bu bölgelerin ticaret bölgesi olmasından ziyade, serbest bölgeye ithal edilen hammadde ile üretilen ürünlerin ihracatını yapan firmaları kapsayan endüstriyel üretim bölgeleri olmalarıdır. Serbest üretim bölgelerinde üretilen malların ülke piyasasına girişi, söz konusu ülke tarafından yasaklanır. Çünkü bu bölgelerdeki faaliyetler malın imalatına ve imal edilen malın ihracatına yöneliktir. Dolayısıyla bu bölgenin ülke ekonomisine sağlamış olduğu avantajlar; yabancı sermaye ve yeni teknoloji girişlerinin sağlanması, yeni istihdam olanaklarının yaratılması, ileri teknolojili yüksek katmak değer yaratan ihracatın artırılması ve bütün bu etkilerin sonucu ile ülkeye giren döviz rezervlerinin artırılması şeklinde ortaya çıkmaktadır (Orhan, 2003: 120-121).

\subsection{Serbest Bölgelerin Özellikleri}

Serbest bölgeler gelişmiş ülkeler ve gelişmekte olan ülkeler açısından farklı özellikler gösterse de bu bölgelerin genel özellikleri şu şekildedir (Gümüş, 2007: 49):

- Gümrük bölgesi dışında olmakla beraber siyasi olarak bağımsız değildirler,

- Sinırları belirlenmiştir,

- Kurulduğu ilgili şehir veya bölgenin belirli bir kısmında kurulur,

- Bu bölgelerde konaklama yapılması mümkün değildir,

- Özel ve resmi kurumlar tarafından işletilebilirler,

- Bu bölgelerde değişik ticari faaliyetler yapılabilir.

\section{SERBEST BÖLGELERİN SAĞLADIKLARI AVANTAJLAR VE EKONOMIKK ETKILLERİ}

Çalışmanın bu kısmında serbest bölgelerin sağladıkları avantajlara değinilecek ve serbest bölgelerin olumlu ve olumsuz ekonomik etkileri ile yerli ve yabancı ekonomik aktörler üzerindeki olası etkileri üzerinde durulacaktır. 


\subsection{Serbest Bölgelerin Avantajları}

Serbest bölgelerin avantajları şunlardır (Canıtez ve diğ., 2016: 40):

- İşletmeler serbest bölgelerde gelir ve kurumlar vergisi ödemezler,

- Serbest bölgelerde çalışanların da gelir vergisi ödemeleri nedeniyle için işçilik maliyetleri düşüktür,

- Yabanci ülkelerden gelen ürünler için gümrük vergisi ödenmez,

- Serbest bölgeler gümrüksüz alan olduğu için bu bölgelerde büyük miktarlarda mal stoklaması yapılabilir,

- Türkiye'den serbest bölgelere yapılan ticari faaliyet ihracat sayıldığı için, serbest bölgelerdeki işletmeler KDV'den istisnadır,

- Kazanılan gelirler serbestçe istenilen ülkelere transfer edilebilir,

- Bürokratik işlemler en aza inmiştir,

- Bölgedeki tüm altyapı işlemleri tek elde toplanmıştır,

- Yatırımcilar istedikleri zaman işletmelerini başkalarına devredebilirler,

- Serbest bölgelerdeki işletmeler bankalarından daha cazip koşullarda krediler temin edilebilir,

- Serbest bölgeler genellikle büyük limanlarda, uluslararası nitelikteki havaalanları ve önemli karayolu bağlantıları üzerinde kuruldukları için, lojistik açıdan işletmelere büyük olanaklar sağlarlar.

Bu çerçevede Türkiye'den bir serbest bölgeye yapılan mal sevkiyatı ihracat olarak düşünülmektedir. Benzer şekilde Türkiye'deki bir serbest bölgeden ihracatçının herhangi bir ülkeye mal göndermesi de, ülke içine mal girişi olmadan gönderildiği için transit ticaret olarak algılanmaktadır. Ancak, Türkiye'den serbest bölgeye gönderilen bir mal, tekrar iç pazara alınmak istenirse, bu defa yapılan işlem ithalat olarak kabul görmektedir ve Serbest Dolaşıma Giriş Rejimine tabi olarak işlem görür. Dolayısıyla, serbest bölgeler Türkiye'nin siyasi sınırları içinde bulunmakla beraber, mal giriş çıkışları bağlamında yurtdışı olarak kabul edilmektedir.

Serbest bölgelerin sağlamış olduğu bir diğer avantaj da, üretimde kullanılmak üzere hammadde ithalatının gümrük vergisinden muaf olmasıdır. Bu durum, serbest bölgelerde ihracata yönelik üretim faaliyetinde bulunan firmaların maliyetlerini düşürerek, yurt dışı piyasalarda uluslararası rekabet güçlerini artırmaktadır. Ayrıca, serbest bölgelerde faaliyet gösteren firmalar, Türkiye'den KDV'siz mal ve hizmet satın alabilirler. Bu açıdan, bu bölgelerde gümrüksüz düzenli girdi temin edilmesi suretiyle, ihracatın artırılmasını sağlayacak ortamın oluşturulmasına zemin hazırlanmış olacaktır (Türkgenci, 2008: 50).

\subsection{Serbest Bölgelerin Ekonomik Etkileri}

Ülkelerin dış ticaret hacimlerini artırmak için kullandıkları araçlardan birisi olan serbest bölgeler kuruldukları bölge ve ülke üzerinde bazı ekonomik etkilere sahiptirler. Bu etkiler olumlu ve olumsuz etkiler olmak üzere ikiye ayrılarak incelenebilir (Uzay ve Tıraş, 2009: 250):

Serbest bölgelerin ihracat ve döviz kazançlarını artırması, ithalatı kolaylaştırması, yabancı sermaye ve teknoloji transferini kolaylaştırması, transit ticaret, liman ve taşımacılık hizmetlerine etkisi, istihdam artırıcı etkisi, yeni politikaların denenmesine imkân sağlaması ve kıyı bankacılığı imkânı sağlaması gibi etkiler serbest bölgelerin olumlu ekonomik etkilerini oluşturmaktadır.

Serbest bölgelerin en önemli olumlu etkisi, üretim maliyetlerinin azalması ile ilgilidir. Serbest bölgelerde üretim yapan firmalar, kullandıkları ithal girdilerde kesinti olması halinde ve uygun fiyatlarla dış piyasalardan büyük miktarda girdi temin ettiklerinde, bu girdileri ihtiyaçlarına uygun olarak kısım kısım ithal ederek, depolama ve gümrük vergisi giderlerini azaltmaktadırlar. Böylece firmalar hem üretim maliyetlerini azaltmış, hem de hammadde temini sırasındaki gecikmelerden kurtulmuş olur. Bunun neticesinde üretim maliyetlerinin azaltılması söz konusu olacaktır böylece üretim artacak ve söz konusu üretilen ürünlerin dış piyasaya satılması daha kolay hale gelecek ve ekonomik büyüme olumlu yönde etkilenecektir (Küçükarslan, 2001: 76).

Serbest bölgelerin ithalat baskısı yaratması, serbest bölgelerdeki firmaların yerli firmalara rakip olması, sosyal yapının bozulması ve ücret eşitsizliği, ekonomiyi yönlendirmede etkinliğin azalması, kaçakçılı̆̆ın artması eğilimi, tekelleşmeyi hızlandırması, yatırımların olumsuz etkilenmesi, yabancı yatırımların ülke ekonomisine katkılarının azalması, serbest bölgelerin kurulma maliyetlerinin yüksek olması ve çevre kirliliği sorunu gibi etkiler, serbest bölgelerin olumsuz ekonomik etkileri olarak değerlendirilebilir.

Serbest bölgelerin en olumsuz ekonomik etkilerinden birisi, ithalat baskısı yaratmasıdır. Özellikle gelişmekte olan ülkelerde serbest bölgelerde üretim açısından ucuz olan hammaddelerin kullanılması tercih edildiği için, yapılacak üretim ihraç edilmek amacıyla bile üretilse, hammadde temini dışardan sağlandığı için ithalatı cazip hale getirebilmektedir. Önemli sayılabilecek bir diğer olumsuz etki ise, serbest bölgelerdeki yabancı firmaların yerli firmalara rakip olmasıdır. Serbest bölgelerde faaliyet gösteren ve üretim yapan yabanc1 
firmalar, ülkenin üretim girdilerini kullanarak, yerli firmalar ile aynı ürünleri ürettiklerinde, yerli firmaları rekabet yönünden zorlamaktadırlar. Bu durum ülkenin ihracatını artırmak isterken, serbest bölgelerdeki yabancı firmalara sağlanan kolaylıklar nedeniyle yerli firmalar ellerindeki mevcut dış pazarları yabancı firmalara kaptırabilirler (Gümüş, 2007: 51).

Serbest Bölgelerin işgücü arz edenler, tüketiciler, serbest bölgedeki ve serbest bölge dışındaki üreticiler ve hükümet açısından, yerli ve yabancı ekonomik aktörler üzerindeki olumlu ve olumsuz etkileri Tablo 1'de özetlenmiştir.

Tablo 1. Serbest Bölgelerin Yerli ve Yabancı Ekonomik Aktörler Üzerindeki Olası Etkileri

\begin{tabular}{|c|c|c|}
\hline & Yerli Aktörler & Yabanci Aktörler \\
\hline İşgücü Arz Edenler & $\begin{array}{l}\text { (1)SB'de ücreti iyi olan bir iş } \\
\text { bulabilirler. }\end{array}$ & $\begin{array}{l}\text { (7)SB'de ücreti iyi olan bir iş } \\
\text { bulabilirler. }\end{array}$ \\
\hline Tüketiciler & $\begin{array}{l}\text { (2)SB'den EÜ'ye ithal edilen } \\
\text { malları daha ucuza temin ederler. }\end{array}$ & $\begin{array}{l}\text { (8)SB aracılı̆̆ıyla kendi ülkelerine } \\
\text { ithalat gerçekleştirildiği için, söz } \\
\text { konusu mallara daha az ücret öderler. }\end{array}$ \\
\hline SB'deki Üreticiler & $\begin{array}{l}\text { (3)EÜ'ye kıyasla daha düşük } \\
\text { maliyet ile üretimde yapabilirler. } \\
\text { (4)YÜ'ye daha fazla ihracat } \\
\text { gerçekleştirirler. }\end{array}$ & $\begin{array}{l}\text { (9)EÜ’ye ve YÜ'ye SB vasitasiyla } \\
\text { daha fazla mal satabilirler. }\end{array}$ \\
\hline $\begin{array}{l}\text { SB'nin Dışındaki } \\
\text { Üreticiler }\end{array}$ & $\begin{array}{l}\text { (5)SB'deki yapilacak ithalat ile } \\
\text { ilgili olarak rekabet güçlerini } \\
\text { kaybedebilirler. }\end{array}$ & (10)Önemli bir etki gerçekleşmez. \\
\hline Hükümet & $\begin{array}{l}\text { (6) Vergisel teşvikler açısından, } \\
\text { vergi gelir kaybına uğrarlar. }\end{array}$ & (11) Önemli bir etki gerçekleşmez. \\
\hline
\end{tabular}

SB: Serbest Bölge

EÜ: Ev Sahibi Ülke

YÜ: Yabancı Ülkeler

Kaynak: Kibritçioğlu, 1997: 81.

\section{SERBEST BÖLGELERDE FAALIYYT GÖSTEREN İŞLETMELERDE YENI VERGİSEL VE YASAL DÜZENLEMELER}

13 Mart 2017 tarihli ve 2017/10051 sayılı Bakanlar Kurulu Kararı ile yürürlüğe konulan Serbest Bölgelerde Türk Lirası ile Yapılabilecek Ödemeler Hakkında Karar yürürlükten kaldırılmıştır. Bakanlar Kurulu tarafından serbest bölgelerden diğer ülkeler dışındaki ticarette TL kullanılması gerekliliğini öngören "Serbest Bölgelerde Türk Liras1 ile Yapılabilecek Ödemeler Hakkında Karar" yeniden düzenlenmiştir. Buna göre serbest bölgelerdeki faaliyetler ile ilgili her türlü ödeme döviz veya Türk Lirası ile de yapılabilir. Önceden bu ödemeler yalnızca yabancı para ile yapılabiliyorken bu tarihten itibaren Türk Lirası ile de yapılabilecektir (Bakanlar Kurulu Karar1, 2017/10051).

Serbest bölgelerdeki işletmeler yabancı uyruklu veya yerli olsun gümrük hattı dışında sayılırlar. Yeni düzenleme, gümrük hattı dışındaki bir şirketi her gün Türk Lirası ile yabancı para birimleri arasındaki kur hareketlerini takip etmeye ve özellikle Türkiye den temin edilen girdilere bağlı maliyetlerini her gün güncellemeye zorlamaktadır.

Çalışmanın bu bölümünde, çalışmanın temel amacını teşkil eden serbest bölgelerde faaliyet gösteren işletmelerin bölgedeki faaliyetleri ile ilgili yürürlükte bulunan vergisel teşvikler değerlendirilmektedir. Kurumlar Vergisi Kanunu, Gelir Vergisi Kanunu ve Katma Değer Vergisi Kanunu ile diğer mali mevzuat hükümleri doğrultusunda serbest bölgelerde uygulanan yeni vergisel ve yasal düzenlemeler aşağıda başl1klar halinde değerlendirilecektir.

\subsection{Acele Kamulaştırma Hakkı}

24 Şubat 2017 tarihinde 29989 sayılı Resmi Gazetede yayımlanan 6772 Sayılı kanunun ilk maddesi ile 3218 Sayılı Kanunu'nun "Bölgenin Düzenlenme Esasları" başlı̆̆ını taşıyan beşinci maddesinde yapılan değişiklik sonrasında serbest bölge olması kararlaştırılan yerlerdeki arazi ve tesislerin acele kamulaştırılabilmesine Bakanlar Kurulu karar verebilecektir. Bu kamulaştırılması kararlaştırılan arazi ve tesisler için kamulaştırma bedeli ve sonrasında oluşacak masrafların, serbest bölge işleticisi şirketler tarafından karşılanabilmesi için gerekli düzenlemeler yapılmıştır. 
Devletin hakimiyeti ve tasarrufu altında bulunan yer ve bunlar üzerinde inşa edilmiş tesis ile binaların kiralanabilmesi veya aynı süre ile tekrar kullanılabilmesine izin verilebilecektir. Türk Silahlı Kuvvetlerine (TSK) kullanımına verilen bina ve araziler için ise Milli Savunma Bakanlı̆̆ı'ndan görüş alınacaktır.

\subsection{Muafiyet ve Teşviklerden Yararlanma}

6772 Sayılı Kanunun ikinci maddesi ve Serbest Bölge Kanunu'nun "Muafiyet ve Teşvikler" başlığının altıncı maddesinde yer alan serbest bölge ile ilgili mevcut tanıma yer ve sınırları Bakanlar Kurulu tarafindan belirlenir ifadesi eklenmiştir. Maddenin ilk bendini şöyle ifade edebiliriz: Serbest bölgeler Türkiye Gümrük Bölgesinin bir parçasıdır. Bakanlar Kurulu tarafından sınırları ve yeri belirlenir. Serbest dolaşıma girmemiş olan mal herhangi bir gümrük rejimine tabi tutulmaz. Ayrıca bu bölgeler; dolaşıma girmeden gümrük mevzuatındaki hususlar dışında kullanılmamak üzere malların depolandığı ve ticaret politikası önlemleri, ithalat vergileri ve kambiyo mevzuatı açısından Türkiye Gümrük Bölgesi dışında kalan eşyanın ihraç edilmesine olanak sağlanan yerlerdir.

Bununla birlikte yine aynı maddenin dördüncü fikrasında yapılan değişiklik sonucunda teşviklerden yararlanan kullanıcılar ve işleticiler ile diğer kullanıcılar birbirinden ayrılmaktadır. Bu düzenleme ile kazançları gelir veya kurumlar vergisinden muaf kullanıcı ve işleticiler, Bakanlar Kurulu tarafindan belirlenen vergi dışı teşviklerden yatırım ve üretim aşamalarında yine aynı şekilde faydalanmaya devam edeceklerdir. Kazançları itibariyle kurumlar veya gelir vergisinden istisna tutulmamış diğer kullanıcılar ise yararlanmadıkları vergi/vergi dışı teşviklerden yatırım ve işletme süreçlerinde, ilgili mevzuat çerçevesinde izin verilen şekilde yararlanabileceklerdir.

\subsection{Serbest Bölgelerin Gelir ve Harcamaları}

Bölgedeki iç satışlara konu olan özel hesap ücreti tahsilatı, "Serbest Bölgelerin Gelir ve Harcamaları" başlı̆g altında kanunun üçüncü maddesinde açıklığa kavuşturulmuştur. Özel hesap ücreti oranları faaliyet alanı, yatırım türü, bölge ve sektöre uygun olarak düzenlenebilecektir. Yurt dışından serbest bölgeye ithal edilen malların, serbest bölgeden Türkiye'ye tekrar ithalatı sırasında FOB değeri üzerinden peşin olmak üzere binde 9, CIF değerleri üzerinden ise yine peşin olmak üzere binde 1 oranında kesintisi yapılacaktır.

Söz konusu maddeye eklenen bir fikra ile öncelikli, stratejik ve büyük ölçekli yatırımlar konusunda, sektörü ve niteliği açısından proje bazında desteklenmesine karar verilen yatırımlar açısından yukarıda verilen FOB ve CIF değerleri üzerinden belirlenen oranları bölge, sektör, faaliyet alanı veya yatırım türü itibarıyla sıfıra indirmeye, kanuni seviyesine kadar artırmaya ve üzerinde değişiklik yapmaya bakanlar kurulu yetkilidir.

Serbest bölgelerdeki faaliyetlerden oluşan alacaklara yönelik vade ve kur farkı gelirleri muafiyet kapsamında yer almaktadır. Bölge faaliyetlerinden elde edilen bu kazancın, yine bölge faaliyetleri için yapılacak ödemelerde kullanılabilmesine kadar geçen sürede geçici olarak değerlendirilmesi sonucu elde edilen repo ve faiz gelirleri için de yine bu muafiyetten faydalanılabilecektir. Bunun dişında, serbest bölgelerde elde edilmiş bile olsa faiz, repo ve benzeri faaliyet dışı gelirlerin istisna kapsamında değerlendirilemediği görülmektedir.

Kanunun dördüncü maddesi ile Serbest Bölgeler Kanunu'nun "Bölgedeki Mallar" başlı̆̆ını taşıyan sekizinci maddesindeki değişiklik sonucu, yatırım amaçlı olarak kullanılan makine ve ekipmanların, onarım ve tamirlerinin Türkiye'de yapılması, ortaya çıkan hurda ve atıkların serbest bölgeden Türkiye'ye gönderilmesi, Türkiye'de yapılacak film çekimlerinde kullanılan ekipmanların bölgeden geçici olarak çıkması ve benzer özellikteki durumlarda vergi mükellefiyetine ilişkin uygulanacak usul ve esaslar bu durumdan ayrı tutulmak kaydıyla, iş ve işlemlerin kolaylaştırılmasına ilişkin hükümler Gümrük ve Ticaret Bakanlığı ile Ekonomi Bakanlığı tarafından birlikte yürütüleceği ifade edilmiştir.

\subsection{Sözleşme Sürelerinin Yenilenmesi, Değişmesi ve Süresinin Uzatılması}

Kanun, işletmelerin sözleşmelerinin yenilenmesi, değiştirilmesi ve süre uzatımlarını beşinci maddeye eklenen ek bir madde ile yeniden düzenlemektedir. Kanuna göre, sözleşme bitmeden, sözleşmede belirtilen taahhütlerin yerine getirilmesi ve ileriye dönük yatırımlara ilişkin taleplerinin kabul edilmesi durumunda mevcutta geçerli olan sözleşmeler tekrar düzenlenerek sözleşme süresi yeniden uzatılabilecektir.

\subsection{Yurt Dışında Bölgelerin Kurulması}

Kanunun altıncı maddesi ve Serbest Bölgeler Kanunu'na "Yurt dışında yeni bölgelerin kurulması" ile ilgili olarak ek bir madde ilave edilmiştir. Düzenlemeye ilişkin olarak, özel bölgelerin, dış ticaret ve lojistik merkezlerinin ülke dışında hangi ülkelerde kurulması gerektiği, bu bölgelerin Türkiye'de ikamet eden yerleşmiş bir şirket vasıtasıyla kurulması veya işletilmesine ve ülke dışında kurulan bu bölgelere Türkiye'de 
mevcut yerleşik şirketler tarafından yapılan yatırımlar için devlet yardımlarını da Bakanlar Kurulu belirleyecektir.

\subsection{Vergi İstisnası}

Kanunun yedinci maddesi ve Serbest Bölgeler Kanunu'nun geçici üçüncü maddesinin 2. fikrasının a bendinin ilk cümlesine yapılan ekleme ile hizmet ihracatının geliştirilmesi bakımından tamir, bakım, onarım, montaj/ demontaj işlemleri, ayrıştırma, paketleme, etiketleme, aktarma (elleçleme), analiz etme ve malın depolama faaliyetlerine gelir veya kurumlar vergisi muafiyeti sağlanacaktır. Bu hizmetler, fiziki olarak Türkiye'de yapılmakla birlikte, bu hizmetten yararlanacakların yurt dışında ikamet etmesi ve hizmete konu olan malların serbest bölgelerden Türkiye'ye herhangi bir girişi yapılmadan bir başka yabancı ülkeye gönderilmesi şartıyla, bu hizmetlerden elde edilen kazançlar gelir ve kurumlar vergisinden istisna edilecektir.

Söz konusu istisna, işletmenin ülke dışına yönelik faaliyetler gerçekleştirmesi durumunda yararlanabileceği bir kazancın muafiyetidir. Bu faaliyetler kapsamında ruhsat temin edecek işletmelerin sadece yurt dışına yönelik faaliyetler gerçekleştirmesi gerekmektedir. Aynı maddenin b bendine yapılan ilavede asgari geçim indirimi uygulaması yer almaktadır. Serbest bölgelerde üretmiş oldukları ürün ve mamüllerin mevcut FOB bedellerinin en az \% 85'ini yurt dışına ihraç eden şirketlerin, çalıştırmış oldukları personel için ödemiş oldukları ücretler üzerinden, asgari geçim indirimi uygulandıktan sonra hesap edilen gelir vergisi, verilecek muhtasar beyanname de tahakkuk eden vergiden indirilerek tamamen terkin edilir.

Değişiklik öncesinde, serbest bölgelerde üretilen ürünlerin FOB bedellerinin en az \%85'ini ihraç eden firmaların istihdam etmiş olduğu personelleri için ödemiş oldukları ücretler gelir vergisinden istisna tutulmaktaydı. Değişiklik sonrasında ücret stopajıyla ilgili teşvik, istihdam edilen kişiden alınıp işverene sağlanmış oldu. Böylece işverenlerin istihdam maliyetleri azaltılmış ve işçi üzerinden hesaplanan gelir vergisi stopajı teşvikinin işverene ait olduğu hususu açıklığa kavuşmuş oldu.

Ayrıca bu \% 85'lik oranı Bakanlar Kurulu \%50'ye kadar indirebilir veya kanuni seviyesine kadar yükseltebilir. Firmanın yıllık satış tutarı \%85'in altında kalırsa mükellefler zamanında tahsil edilmemiş olan vergileri cezasız olarak ödeyecekler fakat zamanı geçmiş olduğu için gecikme zammıyla birlikte tahsil edilecektir (Gelir İdaresi Başkanlığı, 2018).

\subsection{Serbest Bölgeler İçin Geçici Muafiyet}

Kanunun onuncu maddesinde Emlak Vergisi Kanunu'nun Geçici Muaflıklar başlığı altında yer alan beşinci maddenin (f) fikrasına "Organize Sanayi Bölgeleri" ifadesine ek olarak "Serbest Bölgeler" ifadesi de eklenmiştir. Bu bölgelerdeki binaların inşalarının bitimini takip eden bütçe yılından itibaren 5 yıl süre ile geçici emlak vergisi muafiyeti sağlanmıştır. Bakanlar Kurulu tarafından serbest bölge olarak belirlenen araziler geçici emlak vergisi muafiyetinden yararlanabilecektir. Arsalardaki bu muafiyet, kullanıcı lehine tapuda tescilin yapıldığı tarihe kadar geçerli olacaktır. Ekonomi Bakanlığı Serbest Bölgeler Kanunu ve ilgili mevzuata ilişkin düzenleme yapma yetkisine sahiptir.

\subsection{Türkiye Tanıtım Grubu Oluşturulması}

Sektörel tanıtım gruplarının kapatılmasının ardından ihracatın geliştirilmesi, dünya pazarlarında Türk algısının oluşturulması, "Made in Turkey" ve Türkiye imajını arttırmak üzere 12 Ağustos 2017 tarihinde Türkiye Tanıtım Grubu (TTG) kurulmuştur. TTG’nin geliri, ihracat işlemleri üzerinden oluşan FOB bedelinin on binde 3'üne kadar kesilen katkı paylarından karşılanır. Daha önceki Sektörel Tanıtım Grupları Tebliği'nde ihracatçıdan zorunlu yapılan kesintide üst sınır binde 3 iken, bu tebliğ ile kesinti oranı maksimum on binde 3 'e indirildi.

TTG'nin amacı hedef pazarlarda ülkemizin bilinirliğini artırmak, yabancıların aklına Türkiye denilince kalite seviyesi yüksek ürünlerin gelmesini sağlamak, insanları Türkiye'ye gelmeye, Türk ürünlerini kullanmaya ve Türkiye'de yatırım yapmaya teşvik etmektir.

İhracatçı birlikleri gözetiminde bulunan ve birlikte çalışan bu tanıtım gruplarının tasfiye edilmesi, elde ettikleri gelirleri, diğer hak ve varlıklarını Tanıtım Grubu'na devredilmesine ilişkin uygulanacak usul ile esaslar Ekonomi Bakanlığı tarafindan belirlenecektir (30152 Sayılı Resmi Gazete).

\subsection{Yurt Dışı Teşkilatlarındaki Görev Süreleri}

6722 Sayılı Kanun'un onüçüncü maddesiyle, Ekonomi Bakanı, bakanlığın teşkilat ve görevleri hakkında kanun hükmünde kararnameye uygun olarak personelin yurt dışındaki mevcut görev sürelerini yapmış oldukları görev süresinin yarısına kadar uzatabilir. Yurt dışı teşkilatına sürekli görev ile atanabilmeleri için, en 
az üç yıl bu atamanın yapıldığı tarihte merkez teşkilat birimlerinde fiili olarak görev yapmış olmaları gerekmektedir.

Yapılacak görevin gerektirmiş olduğu durumlarda ise müsteşar, müsteşarın yardımcısı, genel müdür ve genel müdüre yakın unvanlar için bu mevcut süre şartı aranmamaktadır.

Yurt dışında görevin gerektirdiği sorumlulukları yapmayan ve belirlenen performansı göstermeyen ve haklarında ceza soruşturması bulunan memurlar ekonomi bakanının onayıyla merkeze teşkilata sürekli görevle geri çağrılabileceklerdir.

\section{SONUC}

Bu çalışmada, 09 Şubat 2017 tarihinde kabul edilen ve 24 Şubat 2017 tarihinde 29989 sayılı Resmi Gazete'de yayımlanan 6772 Sayılı Kanun ile serbest bölgelerde ortaya çıkan yeni vergisel düzenlemeler incelenmiştir. $\mathrm{Bu}$ kanun ile serbest bölgelerdeki işletmelere sağlanan vergisel teşviklerin kapsamı genişletilmiştir. 6772 Sayılı Kanun ile getirilen en önemli değişikliklerden biri, serbest bölgelerde çalışan personele ödenen ücretlerle ilgilidir.

İlgili kanundan önce, serbest bölgelerde üretilen ürünlerin FOB bedelinin en az \%85'ini ihraç eden işletmelerin, istihdam ettikleri personele ödedikleri ücretlerin gelir vergisinden istisna olması şeklindeydi. Bu durum, özellikle istihdam edilen personeli teşvik etmeye yönelik bir uygulama olarak değerlendirilmekteydi. Ancak, İlgili kanun ile yapılan değişiklik sonucunda, istihdam edilen personele sağlanan teşvik, işverenin teşvik edilmesi şeklinde yer değiştirmiştir. Böylece serbest bölgelerde faaliyet gösteren işletmelerin çalıştırdıkları personel ücretleri gelir vergisi kesintisi sonrası azaltılarak, üretim maliyetlerinde bir azalma beklentisi söz konusu olabilir. Bu durum her ne kadar üretimde artış beklentisine yol açsa da, serbest bölgelerin yeni istihdam olanakları yaratması amacından uzaklaşılmasına sebep olabilir.

Yeni Kanun ile getirilen bir diğer önemli düzenleme, serbest bölgelerde sadece mal üreten işletmelerin değil, bazı hizmet üretimi yapan işletmelerin de gelir ve kurumlar vergisinden istisna edilmesine yöneliktir. Yapılan bu düzenleme ile serbest bölgelerde mal üretimi yapan işletmelerin sağladıkları kazançlara getirilen istisna kapsamı genişletilerek; bakım, onarım, tamir, montaj, demontaj, aktarma (elleçleme), ayrıştırma, paketleme, etiketleme, test etme ve depolama hizmetlerini yapan işletmelerin elde ettikleri kazançlar da bazı şartlar dâhilinde istisna kapsamına dâhil edilmiştir. Serbest bölgelerde bu durum etkin kullanıldığı takdirde, hizmet ihracatını geliştirerek, dış ticaret açıklarının azaltılmasında önemli bir uygulama olacaktır.

Serbest bölgelerde uygulanan vergisel teşvikler özellikle üretim ve ihracatın artırılmasında büyük önem arz etmektedir. Söz konusu teşvikler üretim ve pazarlama maliyetlerini düşürerek ülke ekonomisinin rekabet gücünün artması açısından büyük önem taşımaktadır. Bu nedenle serbest bölgelerde faaliyet gösteren firmaların vergisel teşvikleri etkin kullanarak ar-ge faaliyetlerine ağırlık vermesi ve yüksek teknolojili ürün üreterek ihraç etmesi, ülkenin sürdürülebilir ekonomik büyümesinde de önemli bir katk1 sağlayacaktır. 


\section{KAYNAKÇA}

Arslan, İbrahim ve Sevda Yapraklı, (2007) "Serbest Bölgelerin Ekonomik Etkileri: Gaziantep Serbest Bölgesi'nin Etkilerine İlişkin Bir Saha Araştırması", Gaziantep Üniversitesi Sosyal Bilimler Dergisi, 6(2), 91-102.

Avcı, Mehmet ve Didem Erek, (2018) "Türkiye'de Serbest Bölge Uygulamalarının Yabancı Sermaye Girişine Katkısının Değerlendirilmesi: Ege Serbest Bölge Örneği”, Ekonomi ve Yönetim Araştırmaları Dergisi, 7(1), 200-227.

Bakan, Sumru ve Seyit Gökmen, (2014) "Serbest Bölgeler ve Dış Ticaret İlişkisi: Gaziantep Serbest Bölgesi Örneği”, Elektronik Sosyal Bilimler Dergisi, 13(51), 34-51.

Bakanlar Kurulu Kararı, "BKK 2017/10051 Serbest Bölgelerde Türk Lirası ile Yapılacak Ödemelere İlişkin Kararın Yürürlüğe Konulması Hakkında Karar", Erişim Tarihi 15.09.2018, http://www.resmigazete.gov .tr/eskiler/2017/05/20170511-3.pdf.

Canıtez, Murat ve diğ., (2016) Uygulamalı ihracat-İthalat İşlemler ve Dökümantasyon, Güncellenmiş 4. Baskı, Gazi Kitabevi, Ankara.

Cıll1, Ebru, (2013) "Türkiye'de Serbest Bölgeler ve Vergi Uygulamaları: Bursa Serbest Bölgesi Özelinde Bir Değerlendirme”, Yüksek Lisans Tezi, Uşak Üniversitesi Sosyal Bilimler Enstitüsü, Uşak.

Çetinkaya, Özhan ve Nur Belkız Bektaş, (2014) "Serbest Bölgeler ve Ekonomik İşlevleri Yönüyle Değerlendirilmesi”, U.Ü. Sosyal Bilimler Enstitüsü Dergisi, 7(2), 53-70.

Dabour, Nabil Md, (1999) "Free Trade Zones in the Aftermath of the Uruguay Round: Experience of Selected OIC Member Countries", Journal of Economic Cooperation, 20(4), 1-33.

Demirci, Ayhan ve Dilara Berrak Tarhan, (2016) "Serbest Bölgelerin Dış Ticaretteki Önemi ve Türkiye’deki Serbest Bölgelerin Etkinliklerinin Veri Zarflama Analizi ile İncelenmesi", Toros Üniversitesi İISBF Sosyal Bilimler Dergisi, 3(6), 31-53.

Ebiri, Kevser Altay, (2000) “Türkiye'deki Serbest Bölgelerin Ekonomiye Etkileri ve Vergisel Boyutu, Vergi Raporu Dergisi, 47, 45- 51.

Gelir İdaresi Başkanlığı, "Serbest Bölgede Üretilen Ürünlerin FOB Bedeli Üzerinden İhraç Oranının Şirketin Kendi Talebiyle \%50'ye Düşürülmesi Durumunda Gelir Vergisi İstisnası Uygulanıp Uygulanamayacağı", Erişim Tarihi 09.10.2018, https://www.verginet.net/dtt/11/ozelge-2018-2.aspx?oz $\mathrm{ID}=1671$.

Gümüş, Erhan, (2007) "Serbest Bölgelerde Vergi Uygulamalarının Değerlendirilmesi”, Atatürk Üniversitesi İktisadi ve İdari Bilimler Dergisi, 21(1), 47-60.

Kibritçioğlu, Aykut, (1997) "Serbest Bölgelerin Olası Makroekonomik Etkileri ve Bazı Düşündürdükleri", Liberal Düşünce Dergisi, 6, 75-88.

Küçükarslan, Özgür, (2001) “Dış Ticarette Bankacılık ve Gümrük Prosedürü”, Yüksek Lisans Tezi, Karadeniz Teknik Üniversitesi Sosyal Bilimler Enstitüsü, Trabzon.

Miyagiwa, Kaz, (1993), "The Locational Choice for Free Trade Zones: Rural Versus Urban Option”, Journal of Development Economics, 40, 187-203.

Orhan, Ayhan, (2003) "Serbest Bölgelerin Sağladığı Avantajlar: Kosbaş Örneği”, Kocaeli Üniversitesi Sosyal Bilimler Enstitüsü Dergisi, 2003/1, 117-131.

Öztürk, Lütfü, (2013) “Serbest Bölgelerin Geleceği: Türkiye Açısından Değerlendirilmesi”, Uluslararası Yönetim İktisat ve İşletme Dergisi, 9(19), 75-86.

Tüzün Rad ve diğ. (2006) "Serbest Bölgelerin Kalkınmaya Etkileri: Mersin Serbest Bölgesi”, Akademik Bakış Dergisi, $55,288-305$.

Tümenbatur, Atiye, (2012) “Serbest Bölgeler ve Türkiye Ekonomisine Katkıları Üzerine Bir Değerlendirme”, C.U. Sosyal Bilimler Enstitüsü Dergisi, 21(3), 339-356.

Türkgenci, Gizem, (2008), “Türkiye Serbest Bölgelerinin Kalkınmaya Etkisi”, Uluslararası Ekonomik Sorunlar, 34, 4957.

Ural, Özge, (2009) “AB ve Türkiye'de Serbest Bölgelerin Vergilendirilmesi”, Yüksek Lisans Tezi, İstanbul Üniversitesi Sosyal Bilimler Enstitüsü, İstanbul.

Uzay, Nisfet ve Hayrettin Tiraş, (2009) "Serbest Bölgelerin Ekonomik Etkileri: Kayseri Serbest Bölgesi İçin Bir Uygulama”, Erciyes Üniversitesi Sosyal Bilimler Enstitüsü Dergisi, 26 (1), 247-277.

Yang, Yi.Chih, (2009) "A Comparative Analysis of Free Trade Zone Policies in Taiwan and Korea Based on A Port Hinterland Perspective", Shipping and Logistics, 25(2), 273-303.

Young, Leslie, (1987) "Intermediate Good and The Formational of Duty-Free Zones", Journal of Development Economics, 25, 369-384.

3218 Sayılı Serbest Bölgeler Kanunu, M.5, M.6, M.7, M.8.

4458 Say1lı Gümrük Kanunu, M.152.

6772 Sayılı Serbest Bölgeler Kanunu ile Bazı Kanun ve Kanun Hükmünde Kararnamelerde Değişiklik Yapılmasına Dair Kanun M.1, M.2, M.3, M.4., M.5, M.6, M.7, M.8, M.10, M.13.

30152 Sayılı Resmi Gazete, “Türkiye Tanıtım Grubunun Kuruluş ve Görevleri Hakkında Yönetmelik”, Erişim Tarihi 12.09.2018,

http://www.resmigazete.gov.tr/main.aspx?home=http://www.resmigazete.gov.tr/eskiler/2017/08 /20170812.html. 